\title{
Homeopathic Treatments and their Effect on the Initial Development of Cucumber Plants Grown in Cow Manure Contaminated by Auxinic Herbicide
}

\author{
${ }^{1}$ Ricardo Adriano Felito, ${ }^{2}$ Oscar Mitsuo Yamashita, ${ }^{2}$ Adriano Maltezo da Rocha, ${ }^{3}$ Wagner Gervazio, ${ }^{2}$ Marco \\ Antonio Camillo de Carvalho, ${ }^{2}$ Aureane Cristina Teixeira Ferreira, ${ }^{2}$ Delmonte Roboredo \\ ${ }^{1}$ Programa de Pós-Graduação em Agronomia/Horticultura, Faculdade de Ciências Agronômicas - UNESP, R. Dr. José Barbosa de Barros, 1780 - Jardim Paraiso, \\ Botucatu - SP, 18610-307, Brazil \\ ${ }^{2}$ Programa de Pós-Graduacão em Biodiversidade e Agroecossistemas Amazônicos, UNEMAT, Campus II - Avenida Perimetral Rogério Silva, 4930 - Jardim \\ Flamboyant, Alta Floresta, MT 78580-000, Brazil \\ ${ }^{3}$ Programa de Pós-Graduação em Engenharia Agrí́cola, Faculdade de Engenharia Agrícola, UNICAMP, Avenida Cândido Rondon, 501, Barão Geraldo, \\ Campinas, SP 13083-970, Brazil
}

Correspondence Author: Ricardo Adriano Felito , Programa de Pós-Graduação em Agronomia/Horticultura, Faculdade de Ciências Agronômicas - UNESP, R. Dr. José Barbosa de Barros, 1780 - Jardim Paraiso, Botucatu - SP, 18610-307, Brazil

E-mail: ricardofelito@ hotmail.com

Received date: 28 January 2019, Accepted date: 13 March 2018, Online date: 28 March 2019

Copyright: $\odot 2019$ Ricardo Adriano Felito et al, This is an open-access article distributed under the terms of the Creative Commons Attribution License, which permits unrestricted use, distribution, and reproduction in any medium, provided the original author and source are credited.

\begin{abstract}
(Homeopathic treatments and their effect on the initial development of cucumber plants grown in cow manure contaminated by auxinic herbicide). Homeopathy has been studied worldwide and its beneficial effects have been reported in animals and, more recently, in the healing of plants affected by various diseases, such as the treatment of plants grown on substrates contaminated with herbicide residues. However, information on the response of plants to homeopathic treatment is scarce. This work aimed to evaluate the neutralizing potential of homeopathic preparations on chemical residues of picloram + 2,4-D in bovine manure. After the herbicide contamination of manure, it was applied with each homeopathic treatment every $\mathbf{7}$ days, for a period of $\mathbf{1 0}$ weeks. The treatments consisted of the combination of three homeopathic preparations (Nux vomica, Carbo vegetabilis and Arsenicum album) and five dynamizations $(6 \mathrm{CH}, 12 \mathrm{CH}, 18 \mathrm{CH}, 24 \mathrm{CH}$ and $30 \mathrm{CH}$ ) and two controls = bovine manure without contamination and without homeopathic treatment; $\mathrm{TH}=$ contaminated bovine manure without homeopathic treatment). Samples were taken from each treatment for cucumber cultivation. On the 10th day after sowing, germination, emergence speed index, phytointoxication, aerial and root length and dry mass of the plants were evaluated. All homeopathic preparations worked positively to reduce the toxic effects of 2,4-D + picloram. However, they did not completely neutralize the action of the herbicide on early development of cucumber plants. Thus, it can be concluded that there is no differential response between homeopathic preparations and dynamizations between $6 \mathrm{CH}$ and $30 \mathrm{CH}$ in the expression of the toxic effect on young cucumber plants grown in manure contaminated with 2,4-D + picloram herbicide.
\end{abstract}

Key words: Homeopathy, Nux vomica, Carbo vegetabilis, Arsenicum album, Phytointoxication, Herbicide.

\section{INTRODUCTION}

Livestock grazing is developed an activity considered as pioneer in occupation of the land (Dias Filho, 2014). However, there is a tradition of low investment in the use of technology and supplies for the formation and operation of most Brazilian pastures. Thus, this practice has as main consequence the widespread incidence of degraded pastures. In this context, the stigmatization of livestock developed pasture, seen as essentially unproductive and harmful activity to the environment (Dias Filho, 2014).

High infestation of weeds is one of the biggest problems of the system of production of cattle in Brazil (Santos et al., 2006). In this sense, the control of these undesirable plants in pastures have been directed basically by applying herbicides (Pellegrini et al., 2010). Although this method be considered efficient and economically viable, but the indiscriminate use of these and other pesticides have raised concerns by environmental contamination, especially in the case of herbicides applied in large volume, and many feature extended residual effect (Belo et al., 2011). 
Citation: Ricardo Adriano Felito, et al., Homeopathic Treatments and their Effect on the Initial Development of Cucumber Plants Grown in Cow Manure Contaminated by Auxinic Herbicide. Australian Journal of Basic and Applied Sciences, 13(3): 31-40. DOI: 10.22587/ajbas.2019.13.3.5

Among the largest use herbicides in pasture of Brazil, the molecules of picloram + 2.4-D, which are hormonal herbicides and has been made available to breeders in the form of commercial products with these molecules alone or in a mixture, in different concentrations (Rodrigues and Almeida, 2005).

These herbicides are classified as syntetic auxins, because after your application influence based on similarity to plant hormones such as auxin, potentized way, interfering with normal growth of broad-leaved plants annual and some perennial (Bjorling-Poulsen et al.,2008; Mortensen et al., 2012).

One of the main problems of this and other herbicides is related with your persistence in the environment, leading to contamination of soil and water. These products are characterised by several metabolic disorders in susceptible plants, such as abnormal growth, death root tissues, epinasty and obstruction of the phloem (Rodrigues and Almeida, 2005).

In Brazil, it has been observed, in several situations, the occurrence of food poisoning in susceptible crops sown in recently treated areas with these herbicides or the presence of residues in vegetable and chaff in the own cow manure, often used as organic fertilizer in areas and/or cultures with this purpose.

In this context, the use of cow manure as fertilizer source can be compromised by the residual effect of the compounds present and which could bring beneficial effects to the rural producers on resource optimization in property, it becomes a factor negative and harmful when used in certain crops. Edvan and Carneiro (2011) claim that the use of organic fertilizers is important and viable on cost reduction with chemical fertilizers in farming, providing greater economy of natural resources, in addition to contributing to the improvement of the middle environment.

According to Abreu Junior et al. (2005), the interest of the agricultural use of organic waste is based on your fertility potential. Already Roscoe et al. (2006) state that the use of the organic fertilization occurs due to your lower cost compared to the cost of the mineral fertilizers and the increasing development of organic production systems. In addition to these factors, the waste coming from the cattle industry carry out extremely important function in relation to nutrient cycling, would provide among other advantages, the elimination of cultural remains from other activities, such as horticulture, as well as assist in completion of animal nutrition and to promote the permanence of the producer and of the activity on the property.

In this respect, it is important to search for alternatives that provide the optimization and utilization of these resources present on the property. These agroecological practices considered, become an indispensable tool for farmers by providing your autonomy in the field, reducing your reliance on external inputs, securing it in your property and allowing the cultivation of healthy products, reducing negative impacts on the environment and on society.

One of the most different agroecological practices, homeopathy has been expanding in various regions of the world, having been reported by several authors their beneficial effects on rural properties. According to Andrade and Casali (2011), homeopathy in agriculture, as a general practice, provides rural health, resulting in the abandonment of pesticides and other inputs, providing independence of the producer, especially in areas of family agriculture, justifying your use, mainly in agricultural practices as the cultivation of vegetables.

For the production of vegetables in green belts or on the outskirts of cities of medium and large companies are used to massive way organic waste of animal origin, especially excrements. These products are used as the main nutritional sources for plants that are grown for consumption unprocessed or minimally processed. However, the contamination of this waste can lead to losses in production, ranging from the malformation of the plants until the complete impracticality of cultivation.

Homeopathy becomes a mechanism for management of contaminated manure that easily and cost-effectively, if would be an important tool for small farmers and especially those that have a way of growing the organic agriculture. In this context, it is important to deepen in studies that demonstrate the feasibility of the use of homeopathy in terms of contamination from manure, used in vegetable crops. Moreover, it can be a contribution to obtain new methods or enabling cultivation practices reduce the negative impacts caused by herbicides.

This study aimed to evaluate the potential of homeopathic preparations neutralizer over chemical residues of picloram +2.4 $\mathrm{D}$ in beef manure.

\section{MATERIAL AND METHODS}

The survey was developed in the municipality of Alta Floresta, located in the extreme north of the State of Mato Grosso, Brazil, at $09^{\circ} 52^{\prime} 18^{\prime \prime}$ South latitude and 56 $41^{\prime} 06^{\prime \prime}$ West longitude, at an altitude of $280 \mathrm{~m}$ above sea level. The region's climate is tropical wet (type Am - according to Köppen), with well-defined climatic station, having strict and intense rainy season drought, temperature ranging from 18 to $36{ }^{\circ} \mathrm{C}$, presented $26{ }^{\circ} \mathrm{C}$ average (Carvalho et al., 2014).

The study was conducted in the period from July to December 2016 in experimental station consisting of greenhouse and laboratory, owned by the Seed Technology and Weed Science Laboratory (LaSeM), located in the Technological Center of Southern Amazonia (CETAM) of the University of the State of Mato Grosso, Campus of Alta Floresta, Brazil.

The experimental design was completely randomized design, being the treatments consisting of the combination of three homeopathic preparations (Nux vomica, Carbo vegetabilis and Arsenicum album) and five dynamizations $(6 \mathrm{CH}$; $12 \mathrm{CH}$; $18 \mathrm{CH}$; $24 \mathrm{CH}$ and $30 \mathrm{CH})$ and two witnesses $(\mathrm{T} 0=$ cow manure without pollution and without homeopathic treatment; $\mathrm{TH}=\mathrm{cow}$ manure contaminated without homeopathic treatment) with four replications in $3 \times 7$ factorial scheme.

The procedures were contamination from cattle manure with herbicide used in the control of volunteer plants in pastures and subsequently the application of homeopathic preparations.

For it was collected cool and dry cow manure in a pasture area of a cattle property exempted from the application of herbicides. This material was taken to the dependencies of the laboratory and subsequently held the fermentation process and contamination with the picloram herbicide + 2.4-D (commercial product Artys ${ }^{\circledR}$ ). 
The cow manure was collected in March 2016, being then moistened. This was resolved by approximately weekly 90 days, time when it was considered finalized the process of fermentation. This moment was established for monitoring the elevation of the internal temperature of the pile of cow dung, using a piece of rebar, whose end was kept inside this stack and every 5 days, was removed and checked your heating, indicating an activity of microbiota there present. To be considered complete, the rebar bar no longer warmed.

Preliminary to the main experiment were conducted tests with different levels of contamination from manure, for it was given a contamination level enough to interfere in the normal development of the plants used in the biotest. The tests consisted in the application of increasing doses of syrup of herbicide $\left(0 ; 0.5 ; 1 ; 2 ; 4\right.$ and $8 \mathrm{~mL} \mathrm{~L}^{-1}$ of tanned dung) and later held the cultivation and evaluation of growth of seedlings of cucumber. Then the preliminary trials, was set to use $1.0 \mathrm{~mL}$ of syrup of herbicide per litre of cow manure, tanned in concentration recommended by the manufacturer $\left(256 \mathrm{~g} \mathrm{~L}^{-1}\right.$ of a.i. of picloram $+960 \mathrm{~g} \mathrm{~L}-1$ of a.i. of 2.4-D salt of Dimethylamine or $4.0 \mathrm{~L} \mathrm{ha}^{-1}$ of commercial product Artys $\left.{ }^{\circledR}\right)$.

Manure contamination was carried out with the aid of a costal sprayer pressurized to $\mathrm{CO}_{2}$, armed with a spray tip XR 110:02, calibrated to $1.5 \mathrm{Bar}$, aiming to provide volume of $200 \mathrm{~L} \mathrm{ha}^{-1}$. Soon after the application, the manure contaminated with weedkiller syrup was incorporated manually and vigorously.

Homeopathic preparations of Nux vomica, Carbo vegetabilis and Arsenicum album were chosen according to the first principle of homeopathy, "similius similibus curanter" (like cures like that). For homeopathic preparations, followed the standard methodology proposed by Hahnemann (Barthel, 1993)

First a jar or glass containing the mother tincture (TM) and then used a part of the mother tincture and placed in another glass containing 99 parts of $70 \%$ alcohol or water (this procedure called dilution). Then, stirred by 100 times with rhythmic movements (succussions). This was considered the first pivot (dilution and succussion) that was called 1CH (Centesimal Hahnemanianna). For the $2 \mathrm{CH} 1$ was part of $1 \mathrm{CH}$, which was placed in another glass containing 99 parts of $70 \%$ alcohol or water and sucussioned for 100 times, getting to the end the $2 \mathrm{CH}$. Same procedure was adopted for $3 \mathrm{CH}, 4 \mathrm{CH}$, and so on (Figure 1).

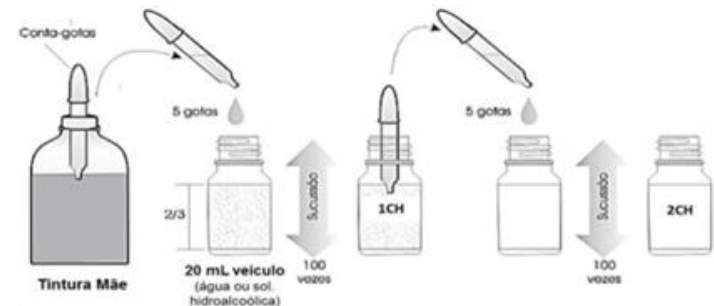

Fig. 1: Diagram of the process of potentisation (dilution and succussion) homeopathic preparations (Bitencourt and Bonato 2008).

On the tenth day after the seeding was carried out the assessment of percentage of emergency speed index (ESI), phytointoxication, aerial length, root length, thickness of stem and total dry mass of all plants of each treatment. Visual analyses were made by assignment of notes, in scale of 0 to 10 (methodology adapted to SBCPD, 1995), where 0 is the absence of any symptoms of phytointoxication and 10 the death of the plant (Table 1 ).

Table 1: Scale of notes used for visual assessment of phytointoxication of herbicides picloram +2.4 -D in seedlings of cucumber.

\begin{tabular}{|c|c|c|}
\hline Concept & Notes & Comments \\
\hline Take & $0-1$ & $\begin{array}{c}\text { Weak or few obvious symptoms. Note zero: no } \\
\text { If you observe any changes in plants }\end{array}$ \\
\hline Acceptable & $2-3$ & Pronounced symptoms, however fully tolerated by the plant. \\
\hline Worrying & $4-5$ & $\begin{array}{c}\text { Symptoms greater than in the previous category, but still recoverable, and without expectations of a } \\
\text { reduction in economic efficiency. }\end{array}$ \\
\hline High & $5-7$ & Irreversible damage, with forecast reduction in economic efficiency. \\
\hline Very high & $7-10$ & $\begin{array}{c}\text { Irreversible damage too severe, with drastic reduction in forecast economic performance. Note 10 for death } \\
\text { of the plant. }\end{array}$ \\
\hline
\end{tabular}

Adapted from SBCPD (1995)

The aerial length, and thickness of the stem were measured with Vernier caliper digital and dry mass with aid of analytical balance. For dry pasta, the material was subjected to drying in an oven of forced circulation of air at $65{ }^{\circ} \mathrm{C}$ for 48 hours.

The speed index (ESI) was conducted noting daily, at the same time, the number of seedlings that had cotiledonar leaves visible. At the end of the test, with the daily data of the number of emerged seedlings, it has been estimated the emergency speed index using the formula proposed by Maguire (1962).

$$
\mathrm{ESI}=\frac{\mathrm{G} 1}{\mathrm{~N} 1}+\frac{\mathrm{G} 2}{\mathrm{~N} 2}+\ldots+\frac{\mathrm{Gn}}{\mathrm{Nn}}
$$

Where:

E.S.I. - emergency speed index.

G1, G2 and Gn - number of normal seedlings computed in the first, second and final count.

$\mathrm{N} 1, \mathrm{~N} 2$ and $\mathrm{Nn}$ - number of days after the test deployment. 
Citation: Ricardo Adriano Felito, et al., Homeopathic Treatments and their Effect on the Initial Development of Cucumber Plants Grown in Cow Manure Contaminated by Auxinic Herbicide. Australian Journal of Basic and Applied Sciences, 13(3): 31-40. DOI: 10.22587/ajbas.2019.13.3.5

The data after analysis of the scapular were submitted to variance analysis by F-test and when significant treatment averages were compared by Tukey test at 5\% probability, using the computer program SISVAR (Ferreira, 2011).

\section{RESULTS AND DISCUSSION}

It was found, by the analysis of variance, which for the variables germination percentage (GER), emergency speed index (ESI), shoot length (SL), root length (RL), thickness of the stem (TS) phytointoxication notes (PN) and mass total dry (MTD), there was significant difference for F-test to the $1 \%$ level of probability for both factors (homeopathy and pivot).

In this way, the action of homeopathic preparations of Nux vomica, Carbo vegetabilis and Arsenicum album and the dynamizations on experimental conditions (Table 2 and Table 3). Has not been verified interaction among the factors for the variables analyzed.

Table 2: Summary of the analysis of variance of percentage of germination percentage (GER), emergency speed index (ESI), shoot length (SL), root length (RL), in study on potential homeopathic preparations neutralizer of Nux vomica, Carbo vegetabilis and Arsenicum album in cow manure contaminated with weedkiller.

\begin{tabular}{|c|c|c|c|c|}
\hline \multirow{2}{*}{ Variation Font } & \multicolumn{4}{|c|}{ Medium Squares } \\
\cline { 2 - 5 } & GER $(\%)$ & ESI & SL $(\mathrm{cm})$ & RL $(\mathrm{cm})$ \\
\hline Homeopathy $(\mathrm{H})$ & $3218.23 * *$ & $0.923 * *$ & $63.099 * *$ & $31.375 * *$ \\
\hline Dynamization $(\mathrm{CH})$ & $2214.37 * *$ & $0.624 * *$ & $38.345^{* *}$ & $20.424 * *$ \\
\hline$(\mathrm{H}) \times \mathrm{CH}$ & $1,7010 \times 10^{-2} \mathrm{~ns}$ & $3,946 \times 10^{-2} \mathrm{~ns}$ & $2,888 \times 10^{-2} \mathrm{~ns}$ & $1,464 \times 10^{-2} \mathrm{~ns}$ \\
\hline Error & 162.74 & 0.044 & 0.489 & 2.161 \\
\hline CV $(\%)$ & 14.41 & 18.83 & 8.98 & 44.00 \\
\hline
\end{tabular}

**-The $1 \%$ probability, by $\mathrm{F}$.

${ }^{\text {ns }}$-Not significant at $5 \%$ probability for the F-test.

Table 3: Summary of the analysis of variance of the thickness of the stem (TS) phytointoxication notes (PN) and mass total dry (MTD) in study on potential homeopathic preparations neutralizer of Nux vomica, Carbo vegetabilis and Arsenicum album in cow manure contaminated with weedkiller.

\begin{tabular}{|c|c|c|c|}
\hline \multirow{2}{*}{ FV } & \multicolumn{3}{|c|}{ Medium Squares } \\
\cline { 2 - 4 } & TS $(\mathrm{mm})$ & PN & MTD $(\mathrm{g})$ \\
\hline Homeopathy $(\mathrm{H})$ & $6.009 * *$ & $57.98 * *$ & $2.154 * *$ \\
\hline Dynamization $(\mathrm{CH})$ & $3.673 * *$ & $38.96 * *$ & $1.426 * *$ \\
\hline$(\mathrm{H}) \times \mathrm{CH}$ & $3,053 \times 10^{-2} \mathrm{~ns}$ & $3,340 \times 10^{-2} \mathrm{~ns}$ & $1,397 \times 10^{-2} \mathrm{~ns}$ \\
\hline Error & 0.061 & 0.023 & 0.007 \\
\hline $\mathrm{CV}(\%)$ & 10.05 & 4.82 & 14.43 \\
\hline
\end{tabular}

**-The $1 \%$ probability, by $\mathrm{F}$.

${ }^{\mathrm{ns}}$-Not significant at $5 \%$ probability for the F-test.

In the evaluation of germination (\%) and IVE, there was variation between 70 and $100 \%$, being recorded higher averages for all homeopathic treatments when compared with the witness $\mathrm{H}$ (manure contaminated with picloram $+2.4-\mathrm{D}$, without homeopathic treatment) that this obtained only $35 \%$ of germination (Table 4 ).

These results indicate the possible restoration of the equilibrium state of the plants tested as a function of the similarity of the homeopathic remedy with the picture of imbalance. It is noted also that there was no difference between the dynamizations ( $\mathrm{p}<$ 0.05) for both variables, however they were significantly above the witness H (Table 4).

Such results are due to reply obtained by the application of homeopathic preparations resulting from the occurrence of the interaction between the medicine diluted and the body out of balance, provide a return to homeostasis (balance) of the individual sick (Vithoulkas, 1980; Bonato, 2004; Duarte, 2007; Majewski et al. 2009), necessary to maintain the stability and survival of seedlings of cucumber.

Through the results obtained in this study, the proper choice of homeopathic medicines intended for neutralization of chemical residues of auxinic herbicides in contact with sensitive plants seeds, such as cucumber. This finding is due to the fact when applying homeopathic preparation can produce healthy plant the same symptoms present in the resulting plant will be the reestablishment, or to minimize, the effects caused by biotic factors or study on self-regulation (Casali et al. 2006; Majewski et al. 2009). Teixeira (2013) explains that homeopathic medicines are employed to the individual in order to arouse a vital reaction against their own body's healing disorders, restoring the normal state of health.

However, even with the positive action of the homeopathic preparations, we observed severe damage by the action of a herbicide, such as resection and leaf epinasty and stem. In addition to these symptoms, the seedlings exhibited wilting and the stems become brittle with more intense symptoms throughout the day until the final evaluation, where it was also possible to observe atrophy of roots. Characteristics like this are peculiar and common in studies with effects of this herbicide on sensitive plants (Cassanego et al. 2010; Yamashita et al. 2010). 
Citation: Ricardo Adriano Felito, et al., Homeopathic Treatments and their Effect on the Initial Development of Cucumber Plants Grown in Cow Manure Contaminated by Auxinic Herbicide. Australian Journal of Basic and Applied Sciences, 13(3): 31-40. DOI: 10.22587/ajbas.2019.13.3.5

Table 4: Germination (\%) and emergency speed index (ESI) of cucumber seedlings sown in cow manure contaminated with picloram + 2.4-D and treated with homeopathic preparations of Nux vomica, Carbo vegetabilis and Arsenicum album.

\begin{tabular}{|c|c|c|}
\hline Homeopatias & Germination (\%) & ESI \\
\hline Witness 0 & $100.00 \mathrm{~A}$ & $1.46 \mathrm{~A}$ \\
\hline Witness H & $35.00 \mathrm{~B}$ & $0.26 \mathrm{C}$ \\
\hline Nux vomica & $90.00 \mathrm{~A}$ & $1.11 \mathrm{~B}$ \\
\hline Carbo vegetabilis & $89.00 \mathrm{~A}$ & $1.10 \mathrm{~B}$ \\
\hline Arsenicum album & $95.00 \mathrm{~A}$ & $1.23 \mathrm{AB}$ \\
\hline Tukey 5\% DMS & 18.40 & 0.30 \\
\hline Dynamizations (CHs) & & \\
\hline Witness 0 & $100.00 \mathrm{~A}$ & $1.46 \mathrm{~A}$ \\
\hline Witness H & $35.00 \mathrm{~B}$ & $0.26 \mathrm{C}$ \\
\hline $6 \mathrm{CH}$ & $85.00 \mathrm{~A}$ & $1.03 \mathrm{~B}$ \\
\hline $12 \mathrm{CH}$ & $90.00 \mathrm{~A}$ & $1.15 \mathrm{AB}$ \\
\hline $18 \mathrm{CH}$ & $91.66 \mathrm{~A}$ & $1.16 \mathrm{AB}$ \\
\hline $24 \mathrm{CH}$ & $95.00 \mathrm{~A}$ & $1.25 \mathrm{AB}$ \\
\hline $30 \mathrm{CH}$ & $95.00 \mathrm{~A}$ & $1.15 \mathrm{AB}$ \\
\hline Tukey 5\% DMS & 20.04 & 0.33 \\
\hline CV (\%) & 14.41 & 18.83 \\
\hline
\end{tabular}

Medium followed by the same letter in the column do not differ significantly from each other by Tukey test at $5 \%$ probability.

This fact may be related with the considerations made by Lisboa et al. (2005), in which the time of response of living organisms to homeopathic medicinal products depends in part on the level of organic poisoning and may be necessary for the reversal of the frame symptomatic a longer application of homeopathic medicines.

Considering the level of contamination used in this study by quantification for phytointoxication notes assignments, the damages were considered severe, so needed longer treatment to minimize the damage caused by intoxication.

For the variable length, the highest average growth were observed at 0 , then Witness for medicines Arsenicum album and Carbo vegetabilis. The lowest averages occurred in Nux vomica and Witness $\mathrm{H}$. Note that there was no significant difference between the dynamizations used, whose higher values were obtained in $18 \mathrm{CH}, 24 \mathrm{CH}$ and with 8.378 .39 and cm respectively; While the worst results were found in Witness $\mathrm{H}$, with an average increase of $1.45 \mathrm{~cm}$ (Table 5).

Table 5: Aerial Length of cucumber seedlings grown in cow manure contaminated with picloram $+2.4-\mathrm{D}$ and treated with homeopathic preparations of Nux vomica, Carbo vegetabilis and Arsenicum album.

\begin{tabular}{|c|c|c|}
\hline Homeopathic preparations & \multicolumn{2}{|c|}{ Length (cm) } \\
\hline Witness 0 & 11.47 & A \\
\hline Witness H & 1.45 & D \\
\hline Nux vomica & 7.014 & C \\
\hline Carbo vegetabilis & 8.01 & BC \\
\hline Arsenicum album & 8.89 & B \\
\hline Tukey 5\% DMS & 1.00 & \\
\hline Dynamizations (CHs) & & \\
\hline Witness 0 & 11.47 & A \\
\hline Witness H & 1.45 & D \\
\hline 6 CH & 7.13 & C \\
\hline $12 \mathrm{CH}$ & 7.85 & BC \\
\hline $18 \mathrm{CH}$ & 8.37 & B \\
\hline $24 \mathrm{CH}$ & 8.39 & B \\
\hline $30 \mathrm{CH}$ & 8.10 & $\mathrm{BC}$ \\
\hline Tukey 5\% DMS & 1.09 & \\
\hline CV (\%) & 8.98 & \\
\hline
\end{tabular}

Medium followed by the same letter in the column do not differ significantly from each other by Tukey test at $5 \%$ probability. Similar to the results of this study, Silva et al. (2012) also found that dilutions between $18 \mathrm{CH}$ and $30 \mathrm{CH}$ provided promising results for the effect of soybean seeds, while aerial part length values for the dilutions $6 \mathrm{CH}$ and $24 \mathrm{CH}$ did not differ from the control, being responses to the present study. In contrast, Marques et al. (2008) reported an increase in the length of the aerial part of the plant spontaneous Sida rhombifolia, studying the dynamizations of $3 \mathrm{CH}, 6 \mathrm{CH}, 12 \mathrm{CH}$ and $30 \mathrm{CH}$ with use of homeopathic preparations of Cymbopogon winterianus. These results showed the peculiarity of each prepared homeopathic, producing in healthy plant symptoms according to the frequency of the waves. In general, the researches with the homeopathic preparations follow these characteristics, and there is variation of response between them. (Armond, 2007; Ucker et al. 2018).

Although no homeopathic treatment have provided normal air development of the plants of cucumber, as noted in 0 , the Witness made up of Arsenicum album demonstrated greater air development when compared to the witness $\mathrm{H}$, in which it 
Citation: Ricardo Adriano Felito, et al., Homeopathic Treatments and their Effect on the Initial Development of Cucumber Plants Grown in Cow Manure Contaminated by Auxinic Herbicide. Australian Journal of Basic and Applied Sciences, 13(3): 31-40. DOI: 10.22587/ajbas.2019.13.3.5

highlighted by the presence of severe symptoms of poisoning caused by picloram $+2.4-\mathrm{D}$, characterized by resection of leaves, curving the sheet on the lower face and curving from the top to the ground.

With respect to the difference in the results in the variable length Rissato et al. (2013) point out that the same medicine can be applied to various agencies and for different situations. In this way, highlights the importance of using in trials, several dynamizations, because the answers can vary in function of the pivot, medicine (Bonato, 2009) and State of the plants (Dutra, 2014).

In a similar manner to the checked in air development, root length was also hampered by the residual action of this herbicide in cow manure, and found major averages in Witness 0 and lower average growth in Witness $\mathrm{H}$. With respect to dynamizations, noted intermediate results among the Witnesses, with greatest growth averages found in $24 \mathrm{CH}$ and $30 \mathrm{CH}$ (Table 6).

Bonfim et al. (2008) also found that Arnica montana dilutions $3 \mathrm{CH}$ and $6 \mathrm{CH}$ provided an increase in the length of the roots of Rosmarinus officinalis and Lippia alba. In other research, Bonfim et al. (2010) observed an increase of the root length of seedlings of lettuce treated with Calcarea anhydrase or Alumina with $6 \mathrm{CH}$ and $12 \mathrm{CH}$. The increased length can occur because the plants respond with a lot of intensity by means of self-regulation that will mobilize your secondary or even primary metabolism, however are unknown the modes of action by which the vital force keeps alive the organic constituents and promotes the integrity of the living organism (Casali et al., 2006; Majewski et al. 2009).

Table 6: Root length of seedlings of cucumber grown in cow manure contaminated with picloram $+2.4-\mathrm{D}$ and treated with homeopathic preparations of Nux vomica, Carbo vegetabilis and Arsenicum album.

\begin{tabular}{|c|c|c|}
\hline Homeopathic preparations & \multicolumn{2}{|c|}{ Root Length $(\mathrm{cm})$} \\
\hline Witness 0 & 8.06 & $\mathrm{~A}$ \\
\hline Witness H & 0.85 & $\mathrm{C}$ \\
\hline Nux vomica & 2.74 & $\mathrm{BC}$ \\
\hline Carbo vegetabilis & 3.09 & $\mathrm{~B}$ \\
\hline Arsenicum album & 3.74 & $\mathrm{~B}$ \\
\hline Tukey 5\% DMS & 2.12 & \\
\hline Dynamizations (CHs) & & \\
\hline Witness 0 & 8.06 & $\mathrm{~A}$ \\
\hline Witness H & 0.85 & $\mathrm{C}$ \\
\hline 6 CH & 3.03 & BC \\
\hline $12 \mathrm{CH}$ & 2.81 & $\mathrm{BC}$ \\
\hline $18 \mathrm{CH}$ & 3.09 & $\mathrm{BC}$ \\
\hline $24 \mathrm{CH}$ & 3.16 & $\mathrm{~B}$ \\
\hline $30 \mathrm{CH}$ & 3.85 & $\mathrm{~B}$ \\
\hline Tukey 5\% DMS & 2.30 & \\
\hline CV (\%) & 44.00 & \\
\hline
\end{tabular}

Medium followed by the same letter in the column do not differ significantly from each other by Tukey test at 5\% probability.

Due to large plant biodiversity and different physiological processes of species, as well as different homeopathic preparations and dynamizations use, there has been different results in research on the subject (Betti et al. 2009; Bonato et al. 2009). However, one can observe a similarity in the arguments justifying the importance of homeopathy and consequently the need for studies with different medicines, dynamizations and plant species in various stages of development for guide the use of this practice in vegetable production systems (Silva et al., 2014; Majewski et al. 2009).

The thickness of the stem was influenced significantly $(\mathrm{p}<0.05)$ by application of homeopathic preparations, Carbo vegetabilis was the medicine that provided the medium closest to the Witness 0 , although they differ statistically. Noted positive results obtained when applying homeopathic preparations, whose average thickness of stem were at least five times greater to the witness with herbicide.

The homeopathic medicine Carbo vegetabilis stood out statistically among the other, whose values were $20 \%$ lower than the witness free of herbicide. However Nux vomica and Arsenicum album showed similar behavior among themselves and $17 \%$ lower than the values obtained with the treatment with Carbo vegetabilis (Table 7).

We can tell, based on the results obtained, that the levels of phytointoxication reached the lowest in Witness $\mathrm{H}$, causing the death of the plants. On the other hand, the witness 0 did not present any signs of phytointoxication (Table 8). As for homeopathic preparations, Arsenicum album stood out from the others, with notes of close to 2.5 , being characterized by pronounced symptoms, but tolerated by the plant. Despite of other homeopathic preparations have not been classified with much higher notes, these were framed as different this statistically.

For this same variable, if differentiated responses between the dynamizations, being underage grades were assigned to $18 \mathrm{CH}$ and $30 \mathrm{CH}$ (2.59 and 2.72, respectively), while higher notes, except the witness with herbicide were assigned to $6 \mathrm{CH}$ and $12 \mathrm{CH}$ (3.23 and 3.28, respectively).

It is observed through these results that there was a trend of lower phytointoxication notes as you were raising the dynamizations. Progressive dilutions, accompanied by succussion are less toxic and more potent (Duarte, 2007), so you can check that in the highest dilutions, the homeopathic response was more effective, being assigned notes lower than 3.0. 
Table 7: Thickness of stems of seedlings of cucumber grown in cow manure contaminated with picloram $+2.4-\mathrm{D}$ and treated with homeopathic preparations of Nux vomica, Carbo vegetabilis and Arsenicum album

\begin{tabular}{|c|c|c|}
\hline Homeopathic preparations & \multicolumn{2}{|c|}{ The Stem Thickness (mm) } \\
\hline Witness 0 & 3.56 & $\mathrm{~A}$ \\
\hline Witness H & 0.47 & $\mathrm{D}$ \\
\hline Nux vomica & 2.40 & $\mathrm{C}$ \\
\hline Carbo vegetabilis & 2.85 & $\mathrm{~B}$ \\
\hline Arsenicum album & 2.35 & $\mathrm{C}$ \\
\hline Tukey 5\% DMS & 0.35 & \\
\hline Dynamizations $(\mathrm{CHs})$ & & \\
\hline Witness 0 & 3.56 & $\mathrm{~A}$ \\
\hline Witness H & 0.47 & $\mathrm{C}$ \\
\hline 6 CH & 2.73 & $\mathrm{~B}$ \\
\hline $12 \mathrm{CH}$ & 2.50 & $\mathrm{~B}$ \\
\hline $18 \mathrm{CH}$ & 2.45 & $\mathrm{~B}$ \\
\hline $24 \mathrm{CH}$ & 2.64 & $\mathrm{~B}$ \\
\hline $30 \mathrm{CH}$ & 2.36 & $\mathrm{~B}$ \\
\hline Tukey 5\% DMS & 0.39 & \\
\hline CV $(\%)$ & 10.05 & \\
\hline
\end{tabular}

Medium followed by the same letter in the column do not differ significantly from each other by Tukey test at $5 \%$ probability.

Table 8: Phytointoxication notes of cucumber seedlings grown in cow manure contaminated with picloram $+2.4-\mathrm{D}$ and treated with homeopathic preparations of Nux vomica, Carbo vegetabilis and Arsenicum album.

\begin{tabular}{|c|c|c|}
\hline Homeopathic preparations & \multicolumn{2}{|c|}{ Fitointoxicação } \\
\hline Witness 0 & 0.000 & $\mathrm{~A}$ \\
\hline Witness H & 10.000 & $\mathrm{D}$ \\
\hline Nux vomica & 3.184 & $\mathrm{C}$ \\
\hline Carbo vegetabilis & 3.023 & $\mathrm{C}$ \\
\hline Arsenicum album & 2.680 & $\mathrm{~B}$ \\
\hline Tukey 5\% DMS & 0.220 & \\
\hline Dynamizations (CHs) & & \\
\hline Witness 0 & 0.00 & $\mathrm{~A}$ \\
\hline Witness H & 10.00 & $\mathrm{E}$ \\
\hline $6 \mathrm{CH}$ & 3.23 & $\mathrm{D}$ \\
\hline $12 \mathrm{CH}$ & 3.28 & $\mathrm{D}$ \\
\hline $18 \mathrm{CH}$ & 2.59 & $\mathrm{~B}$ \\
\hline $24 \mathrm{CH}$ & 2.97 & $\mathrm{C}$ \\
\hline $30 \mathrm{CH}$ & 2.72 & $\mathrm{~B}$ \\
\hline Tukey 5\% DMS & 0.24 & \\
\hline CV (\%) & 4.82 & \\
\hline
\end{tabular}

Medium followed by the same letter in the column do not differ significantly from each other by Tukey test at $5 \%$ probability

To the variable total dry mass, there was a significant difference only when compared with the averages of the witnesses, that presented $\mathrm{g}$ 1.91. Witness 0 while the witness $\mathrm{H}$ presented $0.00 \mathrm{~g}$ values among all medicines homeopathic, the behavior of this feature was similar, varying between 0.50 to $0.58 \mathrm{~g}$.

Similar results were also observed comparing the dynamizations with witnesses (Table 9).

Those answers follows the same pattern found by Bonato et al. (2009) in a study on the applicability of homeopathic Sulphur and Arsenicum album in the growth and essential oil content in mint, where verified that there was increased the biomass fresh in boosting $24 \mathrm{CH}$ and $30 \mathrm{CH}$.

Experiments carried out without further research have shown that in consecutive power series, only some of the potencies tested showed effects, similar to the results observed in this study (Majewski et al. 2009). Queiroz (2015) positive response s with homeopathic preparations of Nux vomica in boosting $12 \mathrm{CH}$, providing greater root dry mass content. Marques et al. (2008) also observed increase in fresh weight total to dynamizations $6 \mathrm{CH}, 12 \mathrm{CH}, 24 \mathrm{CH}$ and $30 \mathrm{CH}$ with homeopathic preparations of Cymbopogon winterianus. In this way, as well as in this study, are found evidence and supported by the positive action of the homeopathic medicines application to plants. However, we believe that further research is needed to implement adequate controls to identify specific effects of homeopathic preparations, and it is necessary to include elements for comparison of negative control (Ucker et al. 2018).

Due to the high level of contamination present in cow manure, cucumber plants present in the Witness had already halted growth your $\mathrm{H}$ in the first days after the emergency, resulting in the death of the plants until the moment of the final evaluation, preventing Thus the determination of accumulation of dry mass. The main symptoms observed by residues of the herbicide are similar to the description of Santos et al. (2013), where both the 2.4-D and picloram have caused resection and folding the edges 
Citation: Ricardo Adriano Felito, et al., Homeopathic Treatments and their Effect on the Initial Development of Cucumber Plants Grown in Cow Manure Contaminated by Auxinic Herbicide. Australian Journal of Basic and Applied Sciences, 13(3): 31-40. DOI: 10.22587/ajbas.2019.13.3.5

of the leaves, with posterior chlorosis and necrosis of leaves and stems. These effects are related to the sensitivity of seedlings of cucumber to low concentrations of auxinic herbicides (Nascimento and Yamashita, 2009).

Table 9: Total dry mass of seedlings of cucumber grown in cow manure contaminated with picloram $+2.4-\mathrm{D}$ and treated with homeopathic preparations of Nux vomica, Carbo vegetabilis and Arsenicum album.

\begin{tabular}{|c|c|c|}
\hline Homeopathic preparations & \multicolumn{2}{|c|}{ Total Dry Mass (g) } \\
\hline Witness 0 & 1.919 & A \\
\hline Witness H & 0.000 & C \\
\hline Nux vomica & 0.501 & B \\
\hline Carbo vegetabilis & 0.578 & B \\
\hline Arsenicum album & 0.581 & B \\
\hline Tukey 5\% DMS & 0.12 & \\
\hline Dynamizations (CHs) & & \\
\hline Witness 0 & 1.919 & A \\
\hline Witness H & 0.000 & C \\
\hline 6 CH & 0.517 & B \\
\hline $12 \mathrm{CH}$ & 0.552 & B \\
\hline $18 \mathrm{CH}$ & 0.561 & B \\
\hline $24 \mathrm{CH}$ & 0.567 & B \\
\hline $30 \mathrm{CH}$ & 0.569 & B \\
\hline Tukey 5\% DMS & 0.13 & \\
\hline CV (\%) & 14.43 & \\
\hline
\end{tabular}

Medium followed by the same letter in the column do not differ significantly from each other by Tukey test at $5 \%$ probability.

On the other hand, despite the cucumber plants grown with the presence of homeopathic preparations in the dung do not present normal growth, the same showed significant improvement in your development, providing reaction to interference caused by residues of herbicides and positive response with accumulation of dry mass, resulting from the application of homeopathic preparations. Thus, it is verified that the use of homeopathic preparations and preparations with high dilutions demonstrate great potential to replace the pesticides that are used in several crops and be able to meet the legal requirements in the organic production system (Modolon et al. 2012).

\section{CONCLUSION}

Through this study generates a basis of promising studies for the insertion of homeopathic science applied to the neutralization of chemical residues present in contaminated compounds by auxinic herbicides, which can bring benefits to rural producers. However, it is recommended that future in-depth studies with other dynamizations and medicines, for that might provide answers more expressive.

Homeopathic preparations of Nux vomica, Carbo vegetabilis and Arsenicum album act positively on reduction of toxicity of 2.4-D + picloram contaminated cow manure. However not completely neutralize the action of the herbicide in the early development of cucumber plants.

There is no differential response between homeopathic preparations or in the dynamizations between $6 \mathrm{CH}$ and $30 \mathrm{CH}$ except for the phytointoxication, in the expression of toxic effects in young plants of cucumber plants in manure contaminated with the herbicide 2.4-D + picloram.

\section{ACKNOWLEDGE}

The authors acknowledge the financial support from CAPES / FAPEMAT / Brazil.

\section{Funding Information}

'Not applicable' for that section.

\section{Conflict of Interest}

Authors declare no conflict of interest.

\section{REFERENCES}

Abreu Junior, C.H., A.E. Boaretto, T. Muraoka and J.C. Kiehl, 2005. Agricultural use of potentially polluting organic waste: Chemical properties of soil and plant production. In: Topics in Soil Science, Eds., Torrado, P.V., L.R.F. Alleoni, M. Cooper, A.P. Silva and E.J. Cardoso. Sociedade Brasileira de Ciência do Solo: Viçosa, pp: 391-470.

Andrade, F.M.C. and V.W.D. Casali, 2011. Homeopathy, agroecology and sustainability. Revista Brasileira de Agroecologia, 6(1): 49-56. 
Citation: Ricardo Adriano Felito, et al., Homeopathic Treatments and their Effect on the Initial Development of Cucumber Plants Grown in Cow Manure Contaminated by Auxinic Herbicide. Australian Journal of Basic and Applied Sciences, 13(3): 31-40. DOI: 10.22587/ajbas.2019.13.3.5

Armond, C., 2007. Chemical indicators, growth and bioletrograms of jambu plants (Acmella oleraceae L.), capim-limão (Cymbopogon citratus (DF) Stapf) and folha-da-fortuna (Bryophyllum pinnatum (Lam) Oken) submitted to homeopathic treatments, Thesis, Federal University of Viçosa, Viçosa, MG.

Barthel, P., 1993. The legacy of Hahnemann: the powers Q (LM). Revista de Homeopatia, 58(1): 13-23.

Belo, A.F., A.T.C.P. Coelho, S.P. Tironi, E.A. Ferreira, L.R. Ferreira and A.A. Silva, 2011. Photosynthetic activity of plants grown on soil contaminated with picloram. Planta Daninha, 29(4): 885-892. http://dx.doi.org/10.1590/S010083582011000400019

Betti, L., G. Trebbi, V. Majewsky, C. Scherr, D. Shah-Rossi, T. Jäger and S. Baumgartner, 2009. Use of homeopathic preparations in phytopathological models and in field trials: a critical review. Homeopathy, 98(4):244-266. https://doi.org/10.1016/j.homp.2009.09.008.

Bitencourt D.P. and C.M. Bonato, 2008. Simple homeopathy applied in environmental education. Editora Peabiru.

Bjorling-Poulsen, M., H.R. Anderson and P. Grandjean, 2008. Potential developmental neurotoxicity of pesticides used in Europe. Environmental Health, 7(1): 1-50.

Bonato, C.M., 2004. Homeopathy: physiology and e mechanisms in plants. In the Proceedings of the Seminário sobre Ciências Básicas em Homeopatia, 4. Lages, pp. 38-54.

Bonato, C.M., 2009. Homeopathy in agriculture. In the Proceedings of the Encontro Brasileiro de Homeopatia na Agricultura. AMVHB, Campo Grande, pp.1-14.

Bonato, C.M., G.T. Proença and B. Reis, 2009. Homeopathic drugs Arsenicum album and Sulphur affect the growth and essential oil content in mint (Mentha arvensis L.). Acta Scientiarum, Agronomy, 31(2): 101-105. http://dx.doi.org/10.4025/actasciagron.v31i1.6642

Bonfim, F.P.G., E.R. Martins, R.G. Rodrigues das Dores, C.K.R. Barbosa, V.W.D. Casali, I.C.G. Honório, 2008. Use of homeopathic Arnica montana for the issuance of roots of Rosmarinus officinalis L. and Lippia alba (Mill) N.E.Br. International Journal of High Dilution Research, 7(23): 113-117.

Bonfim, F.P.G., R.G.R. Dores, E.R. Martins and V.W.D. Casali, 2010. Germination and vigor of lettuce seeds (Lactuca sativa L.) pelleted with homeopathic preparations Alumina and Calcarea carbonica subjected to toxic levels of aluminum. International Journal of High Dilution Research, 33(9): 138-146.

Brasil. Agência Nacional de Vigilância Sanitária - ANVISA. 2011. Brazilian Homoeopathic Pharmacopoeia. Atheneu, São Paulo, 3 ed., pp. 1-364

Brasil. Ministério da Agricultura e Reforma Agrária. 2009. Rules for seed analysis. SNDA/DNDV/CLAV, Brasília, pp. 5-39.

Carvalho, M.A.C., O.M. Yamashita and A.F. Silva, 2014. Lettuce cultivars in different growing environments and organic fertilizers in the north of Mato Grosso. Multitemas, 45(1): 47-59.

Casali, V.W.D., D.M. Castro, F.M.C. Andrade and S.P. Lisboa, 2006. Homeopathy bases and principles. UFV, Viçosa, pp. 135150.

Cassanego, M.B.B., A. Droste and P.G. Windischi, 2010. Effects of 2,4-D on the germination of megaspores and initial development of Regnellidium diphyllum Lindman (Monilophyta, Marsileaceae). Brazilian Journal of Biology, 70(2)361-366. http://dx.doi.org/10.1590/S1519-69842010005000014.

Dias Filho, M.B., 2014. Diagnosis of pastures in Brazil. Embrapa Amazônia Oriental, Belém, pp. 19-36.

Duarte, E.S.M., 2007. Growth and essential oil content in Eucalyptus citriodora and Eucalyptus globulus plants treated with homeopathy. Thesis, Federal University of Viçosa, Viçosa, MG.

Dutra, M., T.C. Deboni, P.S.B. Volpi, J.F.G. Matias and B.Z. Nesi, 2014. Productive evaluation of radish subjected to homeopathic preparations of tiririca Cyperus rotundus. Revista Brasileira de Agroecologia, 9(2): 151-159.

Edvan, R.L. and M.S.S. Carneiro, 2011. Use of the bovine digestive system as an organic fertilizer. Revista Brasileira de Tecnologia Aplicada nas Ciências Agrárias, 4(2): 211-225.

Ferreira, D.F., 2011. Sisvar: a computer system of statistical analysis. Ciência e Agrotecnologia, 35(6): 1039-1042. http://dx.doi.org/10.1590/S1413-70542011000600001

Lisboa, S.P., M.C. Cupertino, V.M. Arruda and V.W.D. Casali, 2005. New vision of living organisms and balance by homeopathy. UFV, Viçosa, pp. 90-104.

Maguire, J.D., 1962. Speed of germination aid in selection and evaluation for seedling emergence and vigor. Crop Science, 2(2):170-177.

Majewsky, V., S. Arlt, D. Shah,C. Scherr, T. Jäger, L. Betti,G. Trebbi,L. Bonamin, P. Klocke and S. Baumgartner, 2009. Use of homeopathic preparations in experimental studies with healthy plants. Homeopathy, 98(4):228-43. http://dx.doi.org/10.1016/j.homp.2009.09.012.

Marques, R.M., G.G. Marques Silva and C.M. Bonato, 2008. Effects of high dilutions of Cymbopogon winterianus Jowitt (citronella) on the germination and growth of seedlings of Sida rhombifolia. International Journal of High Dilution Research, 22(7): 31-35.

Modolon T.A., P. Boff; M I.C. Boff and D.J. Miquelluti, 2012. Homeopathic and high dilution preparations for pest management to tomato crop under organic production system. Horticultura Brasileira, 30(1):51-57.http://dx.doi.org/10.1590/S010205362012000100009.

Mortensen, D.A., J.F. Egan, B.D. Maxwell, M.R. Ryan and R.G. Smith, 2012. Navigating a critical juncture for sustainable weed management. BioScience, 62(1): 75-84. https://doi.org/10.1525/bio.2012.62.1.12

Nascimento, E.R. and O.M. Yamashita, 2009. Initial development of olive groves grown on soils contaminated with residues of 2,4-D + picloram. Semina: Ciências Agrárias, 30(1): 47-54. 
Pellegrini, L.G., C. Nabinger, M. Neumann, P.C.F. Carvalho and L.A. Crancio, 2010. Forage production and dynamics of a natural pasture submitted to different methods of control of undesirable species and to fertilization. Revista Brasileira de Zootecnia, 39(11): 2380- 2388.

Queiroz, R.L., 2015. Basil allelopathy and use of homeopathic preparation Nux vomica in lettuce. Thesis, State University of São Paulo Julio Mesquita Filho, Botucatu, SP.

Rissato, B.B., J.R. Stangarlin, S. Coltro, E. Lorenzetti and M.V. Toledo, 2013. Control of Sclerotinia sclerotiorum with homeopathic drugs. In the Proceedings of the International Conference on Homeopathy in Agriculture, pp.2-4.

Rodrigues, B.N. and F.S. Almeida, 2005. Guide of herbicides. IAPAR, 5 ed., Londrina, pp. 571-591.

Roscoe, R., W.A.G.A. Nunes, E. Sagrilo and A.A. Orsuba, 2006. Agricultural use of refrigerator waste as a solid organic fertilizer. Research and Development Bulletin. n. 35, Dourados: Embrapa Agropecuária Oeste, pp. 7-10.

Santos, D.P., R.R. Brava, F.A.R. Guimarães, A.B.R.J. Passos, D.V. Silva, J.B. Santos and M.C. Nery, 2013. Determination of bioindicator species of auxinic herbicide residues. Revista Ceres, 60(3): 354-362. http://dx.doi.org/10.1590/S0034737 X2013000300008.

Santos, M.V., F.C.L. Freitas, F.A. Ferreira, R.G. Viana, L.D. Tuffi Santos and D.M. Fonseca, 2006. Efficacy and persistence in the soil of herbicides used in pasture. Planta Daninha, 24(2): 391-398.

SBCPD - Brazilian Society of the Science of Weeds. 1995, Procedures for installation, evaluation and analysis of experiments with herbicides. SBCPD: Londrina, pp:4-42p.

Silva, H.A.D., A.V. Parizotto, F.C. Moreira, R.M. Marques, B. Reis and C.M. Bonato, 2012. The effect of high dilutions of Pulsatilla nigricans on the vigour of soybean seeds subjected to accelerated aging. Acta Scientiarum. Agronomy, 34(2): 201206. http://dx.doi.org/10.4025/actasciagron.v34i2.13043.

Silva, N.M., B. De Oliveira and S.L.Lima, 2014. Effect of homeopathy on the germination of yellow ipê. Pesquisa Florestal Brasileira, 34(79): 181-186. http://dx.doi.org/10.4336/2014.pfb.34.79.540.

Teixeira, M.Z., 2013. Similia similibus curentur: the principle of homeopathic cure based on modern pharmacology. Revista de Medicina, 92(3): 183-203. https://doi.org/10.11606/issn.1679-9836.v92i3p183-203.

Ucker, A., S. Baumgartner, A. Sokol, R. Huber, P. Doesburg and T. Jäger, 2018. Systematic review of plant-based homeopathic basic research: an update, Homeopathy, 107(2):115-129. http://dx.doi.org/10.1055/s-0038-1639580.

Vithoulkas, G., 1980. Homeopathy: science and healing. Cultrix: São Paulo, pp: 411- 463.

Yamashita, O.M., R.H. Borges and M.A.C. Carvalho, 2010. Effect of three herbicides on germination of Ipomoea quamoclit on moistened substract. Scientific Electronic Journal of Agronomy, 17(1):17-22. 